NASA Technical Memorandum 113127

AIAA-97-3059

\title{
Performance of a FAKEL K10K Resistojet
}

Robert S. Jankovsky and John M. Sankovic

Lewis Research Center

Cleveland, Ohio

Steven Oleson

NYMA, Inc.

Brook Park, Ohio

Prepared for the

33rd Joint Propulsion Conference and Exhibit cosponsored by AIAA, ASME, SAE, and ASEE

Seattle, Washington, July 6-9, 1997

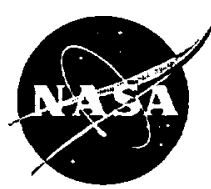

National Aeronautics and

Space Administration 
-

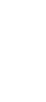

$$
\text { • }
$$




\title{
Performance of a FAKEL K10K Resistojet
}

\author{
Robert S. Jankovsky \\ John M. Sankovic \\ National Aeronautics and Space Administration \\ Lewis Research Center \\ Cleveland, Ohio 44135 \\ Steven Oleson \\ NYMA, Inc. \\ Brookpark, Ohio 44142
}

\begin{abstract}
$\underline{\text { Abstract }}$
A model K10K resistojet produced by FAKEL Enterprise was evaluated at steady-state conditions with both nitrogen and xenon propellants. Performance and operational characteristics were documented for cold gas and heater power levels up to $8 \mathrm{~W}$ at mass flow rates from 0.02 to $0.2 \mathrm{~g} / \mathrm{s}$. Maximum specific impulses of $84 \mathrm{~s}$ on nitrogen and $49 \mathrm{~s}$ on xenon were achieved at the highest specific power levels tested.
\end{abstract}

\section{Introduction}

As part of a continuing effort to evaluate relevant technologies for future U.S. spacecraft, a FAKEL Enterprise model K10K resistojet was obtained and evaluated under a joint NASA / Ballistic Missile Defense Organization (BMDO) program.'

Xenon fueled electrostatic propulsion in the form of gridded ion and Hall effect thrusters is currently of great interest to the spacecraft community. Several Russian spacecraft have used xenon fueled Hall effect thrusters including the Earth observation Meteor 2 and 3 spacecraft and the Gals and Express series of geostationary communication satellites. ${ }^{2}$ U.S. commercial geostationary spacecraft will also soon use xenon electrostatic thrusters; the Hughes HS702 series will use a xenon ion propulsion subsystem for North-South stationkeeping and orbit insertion. ${ }^{2}$ The use of electrostatic thrusters for part of the orbit insertion into geostationary orbit can substantially increase satellite payload. ${ }^{3,4,5}$ Also, NASA will use xenon gridded ion propulsion system for several interplanetary missions with the first, Deep-Space 1, being launched in 1999.6.7

As advanced electrostatic propulsion options are considered for use, additional system level trades are being done to consider simplifying the spacecraft and reducing propulsion system costs by going to a one propellant spacecraft. To this end, propulsion system options such as cold gas Xe thrusters or Xe resistojets are being considered for some low $\Delta \mathrm{V}$ requirements such as momentum wheel desaturation and low $\Delta \mathrm{V}$ attitude control. A specific example of a satellite that uses cold xenon thrusters is the STRV 1A (Space Technology Research Vehicle 1A) launched by an Araine in $1994 .^{2}$ STRV 1A was designed, built and tested by the United Kingdom's Defense Research Agency (DRA) to investigate electrostatic 
charge mitigation via a $\mathrm{Xe}$ plasma neutralizer (first space test of the hollow cathode from the UK-10 gridded ion thruster). The xenon, while primarily carried for the electrostatic discharge experiment, was also used by three cold gas thrusters: two for spinup and one as backup for precession control in case of magnetorquer failure. A second specific example of a spacecraft that was considering a one propellant $\mathrm{Xe}$ propulsion system was NEPSTP (Nuclear Electric Propulsion Space Test Program). ${ }^{8} \quad$ NEPSTP was a BMDO sponsored program that was to demonstrate and evaluate nuclear electric propulsion. This spacecraft was to have a nuclear reactor, powering a Russian Hall effect thruster and a U.S. gridded ion thruster. The spacecraft primary propulsion were these xenon electrostatic thrusters, but the spacecraft required some small $\Delta \mathrm{V}$ attitude control when these thrusters were not firing. Cold gas $\mathrm{Xe}$ thrusters and $\mathrm{Xe}$ resistojets were the propulsion options being considered for this attitude control function because of the system level simplicity an all xenon propulsion system would have.

These types of system level trades will continue to be made for future spacecraft that employ advanced electrostatic thrusters. At this time, evaluation of relevant technologies will continue to gather credible data to use in the trades.

\section{Apparatus}

\section{K10K Thruster}

For the experiments described herein, a model K10K resistojet (Figure 1) obtained from Space Systems / Loral and the Applied Physics Laboratory was tested. This thruster was purchased from FAKEL Enterprise for evaluation for possible use on the NEPSTP spacecraft. The $\mathrm{K} 10 \mathrm{~K}$ is a derivative of the $\mathrm{K} 10$ hydrazine monopropellant thruster design. Over $1000 \mathrm{~K} 10$ monopropellant thrusters have flown on Russian spacecraft. The K10K was designed to leverage this heritage by using as many of the same components as possible. The K10K thruster, however, has a electrothermal accumulator in place of the K10 catalyst bed and a modified injector for gaseous propellants. The $\mathrm{K} 10 \mathrm{~K}$ was designed as a pulsed mode thruster to compliment the Hall effect Stationary Plasma Thruster (SPT) for low $\Delta V$ attitude control on spacecraft. ${ }^{9}$ The configuration and materials of construction of the electrothermal accumulator were unknown to the authors, but the room temperature resistance was found to be nominally 22 Ohms. By inspection, the K10K had a throat diameter of nominally $0.66 \mathrm{~mm}$ and a nozzle exit diameter of nominally $6.6 \mathrm{~mm}$, for a conical nozzle with an area ratio of 100:1. (Figure 2) The thruster firing valve was a solenoid type with a coil resistance of nominally 95 Ohms.

Vacuum Facility

The experiments were conducted in a medium size space simulation facility (VF8) at NASA Lewis Research Center (Figure 3). The facility is a $1.5 \mathrm{~m}$ diameter by $5 \mathrm{~m}$ long vacuum vessel equipped with four $1 \mathrm{~m}$ diameter oil diffusion pumps, using silicon-based oil, with a pumping capacity of $140,000 \mathrm{l} / \mathrm{s}$ at $3 \times 10^{-4}$ torr (air) backed by a rotary blower and two mechanical roughing pumps. The background pressure during most of the experiments was maintained below $5 \times 10^{-4}$ torr. The only tests conditions where the vacuum facility pressure exceeded this was at the high nitrogen flowrates $(>0.07 \mathrm{~g} / \mathrm{s})$. Under these conditions only the rotary blower and mechanical roughing pumps were used and the background pressure was maintained below 0.15 torr. No facility effects at these relatively high pressures were encountered.

\section{Experimental Procedure}

Heater current and voltage, propellant mass flow rate, and thrust were monitored periodically during the test. 
All data were recorded manually. Heater current and voltage were monitored with commercially available digital multimeters. The heater current meter was connected in series with the power supply and the heater voltage meter in parallel. As these were initial tests and the heater materials and configuration were unknown, heater preheating associated with pulsed operation was deemed too risky, initial testing was only performed at steady-state. Testing at steady-state made it possible to regulate propellant mass flow rate by commercially available precision mass flow controllers. One of two controllers (full scale readings of 2 SLM and 10 SLM) were used depending on the mass flow rates desired. Both mass flow controllers were calibrated on nitrogen and xenon. A precision flexure thrust stand was used to measure thrust. The deflection was recorded via a strip chart recorder and calibrated in-situ with precision weights.

To initiate flow to the resistojet, the firing valve was energized by applying $10 \mathrm{~V}$ across the valve coil. This power level (1 W) was chosen as it was the minimum power level that would reliably unseat the valve, hold it open, and minimize heating of the propellant by the valve coil. Propellant mass flow rates were then set by the precision mass flow controller.

Initial cold gas performance was recorded over the maximum range of mass flow rates the test setup could accommodate. They ranged from the maximum the facility could pump and maintain a good vacuum to the lowest the flow controllers could deliver accurately. The cold gas performance was recorded to isolate the unheated nozzle effects. Once at the highest flow rate, the heater was turned on at the lowest power level ( $2 \mathrm{~W})$. Mass flow rate was then decreased while heater power was maintained constant. Once a sweep of flow rate from high to low was made, the heater power was increased to $4.6 \mathrm{~W}$ and another mass flow rate sweep was made. Finally, the heater power was increased to $8 \mathrm{~W}$ and another mass flow rate sweep was made. Data at each point in a mass flow rate sweep was taken at 4 minutes after initial setting of the point. Four minutes was sufficient to reach steady-state from looking at the steadiness of the thrust profiles. Data were taken with both nitrogen and xenon as the propellants. Figures 4 and 5 show the test matrix (heater power and mass flow rate) performed with each propellant.

\section{Results \& Discussion}

Summaries of all the data taken are provided in Tables I and II. Descriptions of the thruster characteristics important to the spacecraft user, specific impulse versus thrust, specific impulse versus specific power (heater input power/mass flow rate), thruster efficiency versus thrust are provided in the following sections.

\section{Nitrogen}

Testing on nitrogen was performed over the mass flow rate range 0.020 to 0.158 $\mathrm{g} / \mathrm{s}$ with cold gas and heater input powers up to $8 \mathrm{~W}$. Plots of specific impulse versus thrust, specific impulse versus specific power, and thruster efficiency versus thrust were made and are provided as figures 6,7 , and 8 , respectively. Figure 6 indicates a cold gas performance of $74 \mathrm{~s}$ at $100 \mathrm{mN}$ thrust. With $8 \mathrm{~W}$ of heater power, a specific impulse of $80 \mathrm{~s}$ is achievable at $100 \mathrm{mN}$ of thrust. However, as the mass flow rate, hence thrust, is decreased below $50 \mathrm{mN}$ the nozzle effects begin to dominate the cold gas performance. This can be seen by the drop off in specific impulse to $65 \mathrm{~s}$ at 20 $\mathrm{mN}$ of thrust. As heater power was increased, the nozzle effects dominated at progressively lower mass flow rates. This is illustrated in the specific impulse versus specific power plot (Figure 7). This plot shows the specific power of the gas at a given heater power where the nozzle effects begin to dominate. It can be seen that for a given power the $\mathrm{K} 10 \mathrm{~K}$ 
has an optimal specific power that is dictated by the nozzle effects. Figure 8 shows thruster efficiency versus thrust characteristic. Here it can be seen that thruster efficiency with cold gas was $85 \%$ at $100 \mathrm{mN}$ and $73.6 \%$ at $20 \mathrm{mN}$. At a heater power of $8 \mathrm{~W}$ the thruster efficiency was $82.2 \%$ at $107.7 \mathrm{mN}$ and $49.3 \%$ at $17.27 \mathrm{mN}$.

\section{Xenon}

Testing on xenon was performed over the mass flow rate range of 0.022 to 0.221 $\mathrm{g} / \mathrm{s}$ with cold gas and heater input powers up to $8.9 \mathrm{~W}$. Plots of specific impulse versus thrust, specific impulse versus specific power and thruster efficiency versus thrust were made and are provided as figures 9,10 , and 11 , respectively. Figure 9 indicates a cold gas specific impulse of $33 \mathrm{~s}$ over the entire range of thrust. As heater power was increased to $7.9 \mathrm{~W}$ a maximum specific impulse of $49.4 \mathrm{~s}$ was achieved at $10.79 \mathrm{mN}$ of thrust. In contrast to the aforementioned nitrogen data no knee in the curve indicating nozzle effects was seen in this plot. This is confirmed by the specific impulse versus specific power plot (Figure 10) in which no discernible knee is evident. The thruster efficiency curve (Figure 11) lends some insight by showing a very low thruster efficiency of $32 \%$ for all conditions tested with xenon as the propellant. It appears that nozzle and/or compressibility effects dominated over the entire xenon test matrix.

\section{Summary}

FAKEL Enterprise's model K10K resistojet was tested at steady-state conditions to give insight to its applicability to future U.S. spacecraft. The thruster was tested on nitrogen and xenon with cold gas and heater powers up to $8 \mathrm{~W}$. A maximum specific impulse of nominally $84 \mathrm{~s}$ on nitrogen and $49 \mathrm{~s}$ on xenon was achieved at a heater power of $8 \mathrm{~W}$ and mass flow rate of $0.02 \mathrm{~g} / \mathrm{s}$. A thruster efficiency of $82 \%$ was achieved with nitrogen at a heater power of $8 \mathrm{~W}$.
When xenon was used as the propellant, a thruster efficiency of $32 \%$ for all conditions tested was achieved, including the cold gas cases.

\section{References}

1. Sankovic, J., Caveny, L., Lynn, P., The BMDO Russian Hall Electric Thruster Technology (RHETT) Program: From Laboratory To Orbit, AIAA 97 2917, July 1997.

2. Wilson, A. (Ed.): Jane's Space Lifetime Directory 1996-1997 on CD ROM.

3. Oleson, S.R. , Curran, F.M., Myers, R.M., "Electric Propulsion For Geostationary Orbit Insertion", NASA TM-106942, August, 1995.

4. Spitzer, A. , "Near Optimal Transfer Orbit Trajectory using Electric Propulsion', Paper AAS-95-215, Feb. 1995.

5. Oleson, S.R. , Myers, R.M., "Launch Vehicle and Power Level Impacts on Electric GEO Insertion", Paper AIAA 962978, July, 1996.

6. Kakuda, R., Sercel, J., and Lee, W., "Small Body Rendezvous Mission Using Solar Electric Ion Propulsion: Low Cost Mission Approach and Technology Requirements, "IAA Paper L-0710, April 1994.

7. Burrows, W.E., "The New Millennium," Air and Space, August/September 1996, pp. 44-53.

8. Herbert, G.A., Day, M., "NEPSTP Propulsion Module Design and Flight Test Plans," 11th Symposium on Space Nuclear Power and Propulsion, January 1994.

9. Personal communication with $\mathrm{V}$. Marashko, Director FAKEL Enterprise, June 24, 1997. 
Table I - FAKEL K10K Thruster Operating on Nitrogen

\begin{tabular}{|c|c|c|c|c|c|c|c|c|}
\hline $\begin{array}{l}\text { Data Point } \\
\text { Number }\end{array}$ & $\begin{array}{l}\text { Heater } \\
\text { Voltage } \\
\text { (V) }\end{array}$ & $\begin{array}{l}\text { Heater } \\
\text { Current } \\
\text { (A) }\end{array}$ & $\begin{array}{l}\text { Heater } \\
\text { Power } \\
\text { (W) }\end{array}$ & $\begin{array}{l}\text { Mass Flow } \\
\text { Rate } \\
(\mathrm{g} / \mathrm{s})\end{array}$ & $\begin{array}{l}\text { Propellant } \\
\text { Feed } \\
\text { Pressure } \\
(\mathrm{kPa})\end{array}$ & $\begin{array}{l}\text { Thrust } \\
(\mathrm{mN})\end{array}$ & $\begin{array}{l}\text { Specific } \\
\text { Impulse } \\
\text { (s) }\end{array}$ & $\begin{array}{c}\text { Thruster } \\
\text { Total } \\
\text { Efficiency } \\
(\%)\end{array}$ \\
\hline 1 & 0.0 & 0.00 & 0.0 & 0.158 & 238.9 & 115.0 & 74.2 & 85.1 \\
\hline 2 & 0.0 & 0.00 & 0.0 & 0.138 & 210.4 & 100.7 & 74.2 & 85.1 \\
\hline 3 & 0.0 & 0.00 & 0.0 & 0.119 & 182.7 & 86.6 & 74.2 & 85.1 \\
\hline 4 & 0.0 & 0.00 & 0.0 & 0.099 & 151.8 & 71.7 & 73.9 & 84.5 \\
\hline 5 & 0.0 & 0.00 & 0.0 & 0.090 & 139.6 & 64.9 & 73.8 & 84.2 \\
\hline 6 & 0.0 & 0.00 & 0.0 & 0.079 & 124.7 & 57.5 & 73.7 & 84.0 \\
\hline 7 & 0.0 & 0.00 & 0.0 & 0.070 & 110.1 & 50.2 & 73.3 & 83.1 \\
\hline 8 & 0.0 & 0.00 & 0.0 & 0.060 & 95.3 & 42.8 & 72.4 & 81.1 \\
\hline 9 & 0.0 & 0.00 & 0.0 & 0.060 & 95.3 & 43.3 & 73.4 & 83.3 \\
\hline 10 & 0.0 & 0.00 & 0.0 & 0.052 & 82.1 & 36.2 & 71.1 & 78.2 \\
\hline 11 & 0.0 & 0.00 & 0.0 & 0.041 & 66.3 & 28.4 & 71.2 & 78.4 \\
\hline 12 & 0.0 & 0.00 & 0.0 & 0.040 & 64.7 & 27.4 & 69.9 & 75.6 \\
\hline 13 & 0.0 & 0.00 & 0.0 & 0.030 & 51.0 & 20.4 & 69.0 & 73.6 \\
\hline 14 & 0.0 & 0.00 & 0.0 & 0.021 & 38.6 & 13.8 & 67.5 & 70.5 \\
\hline 15 & 0.0 & 0.00 & 0.0 & 0.020 & 37.0 & 13.2 & 66.1 & 67.6 \\
\hline 16 & 0.0 & 0.00 & 0.0 & 0.020 & 37.2 & 13.2 & 66.1 & 67.6 \\
\hline 17 & 6.5 & 0.30 & 2.0 & 0.158 & 240.6 & 116.3 & 75.0 & 83.7 \\
\hline 18 & 6.6 & 0.30 & 2.0 & 0.060 & 98.1 & 45.2 & 76.9 & 82.6 \\
\hline 19 & 6.7 & 0.31 & 2.1 & 0.138 & 212.6 & 102.2 & 75.3 & 83.7 \\
\hline 20 & 6.7 & 0.31 & 2.1 & 0.119 & 184.7 & 88.0 & 75.4 & 83.2 \\
\hline 21 & 6.8 & 0.31 & 2.1 & 0.099 & 155.6 & 73.6 & 75.6 & 82.7 \\
\hline 22 & 6.8 & 0.32 & 2.2 & 0.080 & 127.4 & 59.3 & 75.9 & 82.0 \\
\hline 23 & 6.8 & 0.32 & 2.2 & 0.060 & 97.6 & 44.6 & 75.7 & 79.4 \\
\hline 24 & 6.9 & 0.32 & 2.2 & 0.041 & 68.3 & 29.6 & 74.6 & 73.5 \\
\hline 25 & 6.9 & 0.32 & 2.2 & 0.021 & 40.2 & 14.7 & 72.0 & 60.0 \\
\hline 26 & 7.1 & 0.33 & 2.3 & 0.021 & 39.4 & 14.3 & 69.8 & 55.7 \\
\hline 27 & 7.2 & 0.33 & 2.4 & 0.040 & 68.3 & 30.1 & 76.1 & 75.2 \\
\hline 28 & 9.9 & 0.46 & 4.5 & 0.158 & 244.8 & 119.5 & 77.1 & 84.2 \\
\hline 29 & 10.0 & 0.46 & 4.6 & 0.060 & 100.9 & 47.1 & 80.0 & 79.5 \\
\hline 30 & 10.0 & 0.46 & 4.6 & 0.080 & 130.9 & 62.2 & 79.6 & 82.7 \\
\hline 31 & 10.0 & 0.46 & 4.6 & 0.040 & 71.2 & 31.9 & 80.7 & 73.5 \\
\hline 32 & 10.0 & 0.46 & 4.6 & 0.021 & 41.2 & 15.4 & 75.3 & 51.5 \\
\hline 33 & 10.0 & 0.46 & 4.6 & 0.119 & 188.2 & 91.4 & 78.5 & 84.7 \\
\hline 34 & 10.0 & 0.46 & 4.6 & 0.099 & 159.4 & 76.5 & 78.6 & 83.1 \\
\hline 35 & 10.0 & 0.46 & 4.6 & 0.138 & 216.6 & 105.5 & 77.6 & 84.1 \\
\hline 36 & 10.1 & 0.46 & 4.6 & 0.060 & 99.6 & 46.6 & 79.2 & 77.7 \\
\hline 37 & 10.1 & 0.46 & 4.7 & 0.041 & 71.2 & 32.2 & 80.4 & 73.3 \\
\hline 38 & 10.1 & 0.46 & 4.7 & 0.020 & 41.0 & 15.6 & 77.9 & 53.5 \\
\hline 39 & 13.1 & 0.60 & 7.9 & 0.158 & 247.7 & 121.7 & 78.5 & 82.1 \\
\hline 40 & 13.1 & 0.60 & 7.9 & 0.138 & 219.5 & 107.7 & 79.3 & 82.2 \\
\hline 41 & 13.1 & 0.60 & 7.9 & 0.099 & 162.5 & 78.8 & 80.8 & 80.4 \\
\hline 42 & 13.1 & 0.60 & 7.9 & 0.119 & 187.5 & 93.2 & 80.0 & 81.6 \\
\hline 43 & 13.2 & 0.60 & 7.9 & 0.060 & 103.5 & 48.9 & 83.0 & 74.8 \\
\hline 44 & 13.2 & 0.60 & 7.9 & 0.080 & 133.8 & 64.1 & 81.7 & 78.3 \\
\hline 45 & 13.2 & 0.60 & 8.0 & 0.041 & 73.5 & 33.6 & 84.3 & 67.7 \\
\hline 46 & 13.2 & 0.60 & 8.0 & 0.021 & 43.7 & 17.3 & 84.1 & 49.3 \\
\hline
\end{tabular}


Table II - FAKEL K10K Thruster Operating on Xenon

\begin{tabular}{|c|c|c|c|c|c|c|c|c|}
\hline $\begin{array}{c}\text { Data Point } \\
\text { Number }\end{array}$ & $\begin{array}{c}\text { Heater } \\
\text { Voltage } \\
\text { (V) }\end{array}$ & $\begin{array}{c}\text { Heater } \\
\text { Current } \\
\text { (A) }\end{array}$ & $\begin{array}{c}\text { Heater } \\
\text { Power } \\
\text { (W) }\end{array}$ & $\begin{array}{c}\text { Mass } \\
\text { Flow Rate } \\
(\mathrm{g} / \mathrm{s})\end{array}$ & $\begin{array}{l}\text { Propellant } \\
\text { Feed } \\
\text { Pressure } \\
(\mathrm{kPa})\end{array}$ & $\begin{array}{l}\text { Thrust } \\
(\mathrm{mN})\end{array}$ & $\begin{array}{c}\text { Specific } \\
\text { Impulse } \\
\text { (s) }\end{array}$ & $\begin{array}{c}\text { Thruster } \\
\text { Total } \\
\text { Efficiency } \\
(\%)\end{array}$ \\
\hline 1 & 0.0 & 0.00 & 0.0 & 0.220 & 149.8 & 71.6 & 33.2 & 31.6 \\
\hline 2 & 0.0 & 0.00 & 0.0 & 0.169 & 117.6 & 55.1 & 33.3 & 31.8 \\
\hline 3 & 0.0 & 0.00 & 0.0 & 0.118 & 82.5 & 37.8 & 32.7 & 30.6 \\
\hline 4 & 0.0 & 0.00 & 0.0 & 0.058 & 40.5 & 18.0 & 31.7 & 28.8 \\
\hline 5 & 0.0 & 0.00 & 0.0 & 0.046 & 33.7 & 14.6 & 32.4 & 30.1 \\
\hline 6 & 0.0 & 0.00 & 0.0 & 0.034 & 26.8 & 11.3 & 33.5 & 32.1 \\
\hline 7 & 0.0 & 0.00 & 0.0 & 0.022 & 18.8 & 7.5 & 34.0 & 33.1 \\
\hline 8 & 6.5 & 0.30 & 2.0 & 0.119 & 92.8 & 43.9 & 37.7 & 37.1 \\
\hline 9 & 6.6 & 0.30 & 2.0 & 0.169 & 126.7 & 60.5 & 36.6 & 35.9 \\
\hline 10 & 6.6 & 0.30 & 2.0 & 0.169 & 125.4 & 59.6 & 36.0 & 34.7 \\
\hline 11 & 6.7 & 0.31 & 2.1 & 0.022 & 20.3 & 8.7 & 40.1 & 29.5 \\
\hline 12 & 6.7 & 0.31 & 2.1 & 0.034 & 29.6 & 13.4 & 40.3 & 34.1 \\
\hline 13 & 6.8 & 0.31 & 2.1 & 0.058 & 46.1 & 22.1 & 38.8 & 35.5 \\
\hline 14 & 6.8 & 0.31 & 2.1 & 0.046 & 38.0 & 17.8 & 39.3 & 34.8 \\
\hline 15 & 10.1 & 0.46 & 4.6 & 0.169 & 134.8 & 65.9 & 39.8 & 39.0 \\
\hline 16 & 10.1 & 0.46 & 4.6 & 0.058 & 48.0 & 23.0 & 40.4 & 31.7 \\
\hline 17 & 10.1 & 0.46 & 4.7 & 0.058 & 49.1 & 23.8 & 41.9 & 34.0 \\
\hline 18 & 10.1 & 0.46 & 4.7 & 0.118 & 99.2 & 48.6 & 42.1 & 41.1 \\
\hline 19 & 10.1 & 0.46 & 4.7 & 0.046 & 41.3 & 19.8 & 43.8 & 34.3 \\
\hline 20 & 10.1 & 0.46 & 4.7 & 0.022 & 23.3 & 10.1 & 46.3 & 27.2 \\
\hline 21 & 10.1 & 0.46 & 4.7 & 0.034 & 32.7 & 15.1 & 45.0 & 31.9 \\
\hline 22 & 10.1 & 0.46 & 4.7 & 0.221 & 166.0 & 81.5 & 37.6 & 36.0 \\
\hline 23 & 13.2 & 0.60 & 7.9 & 0.022 & 25.3 & 10.8 & 49.4 & 22.2 \\
\hline 24 & 13.3 & 0.60 & 8.0 & 0.034 & 35.5 & 16.2 & 48.3 & 27.9 \\
\hline 25 & 13.3 & 0.60 & 8.0 & 0.046 & 45.0 & 21.4 & 47.3 & 31.5 \\
\hline 26 & 13.3 & 0.60 & 8.0 & 0.058 & 53.9 & 26.3 & 46.3 & 33.8 \\
\hline 27 & 13.9 & 0.63 & 8.7 & 0.221 & 169.3 & 81.7 & 37.7 & 33.0 \\
\hline 28 & 13.9 & 0.63 & 8.8 & 0.120 & 101.3 & 49.3 & 42.0 & 35.2 \\
\hline 29 & 14.0 & 0.63 & 8.9 & 0.120 & 104.1 & 51.7 & 44.1 & 38.6 \\
\hline
\end{tabular}

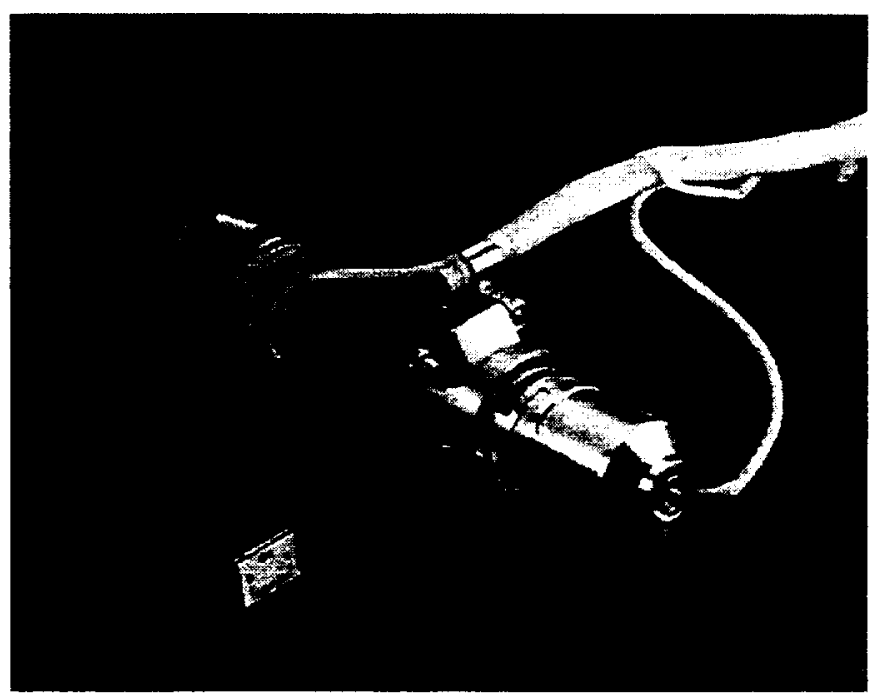

Figure 1 - FAKEL K10K Resistojet 


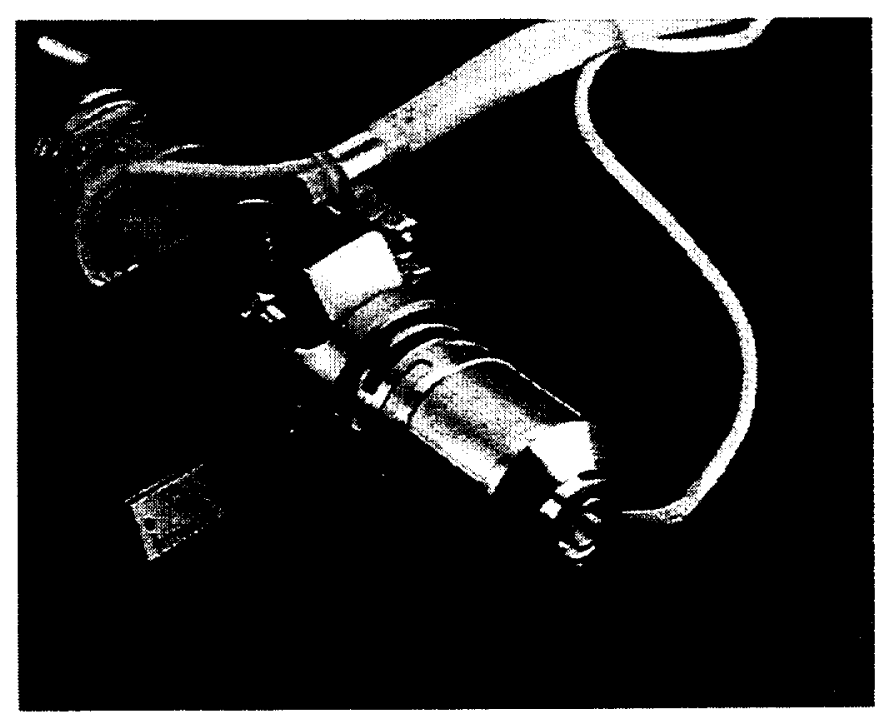

Figure 2 - Close-up of Nozzle Region of FAKEL K10K

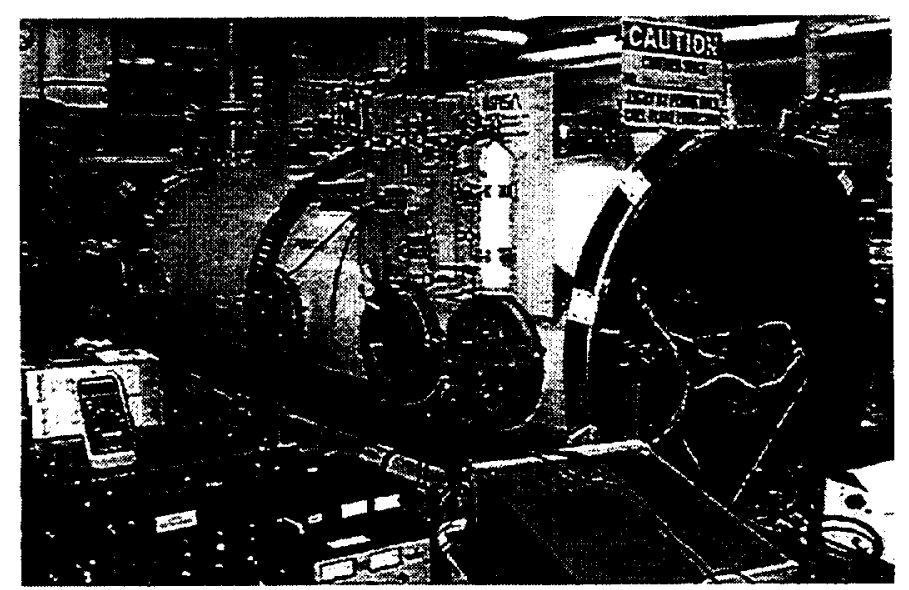

Figure 3 - NASA Lewis Research Center Vacuum Facility 8 


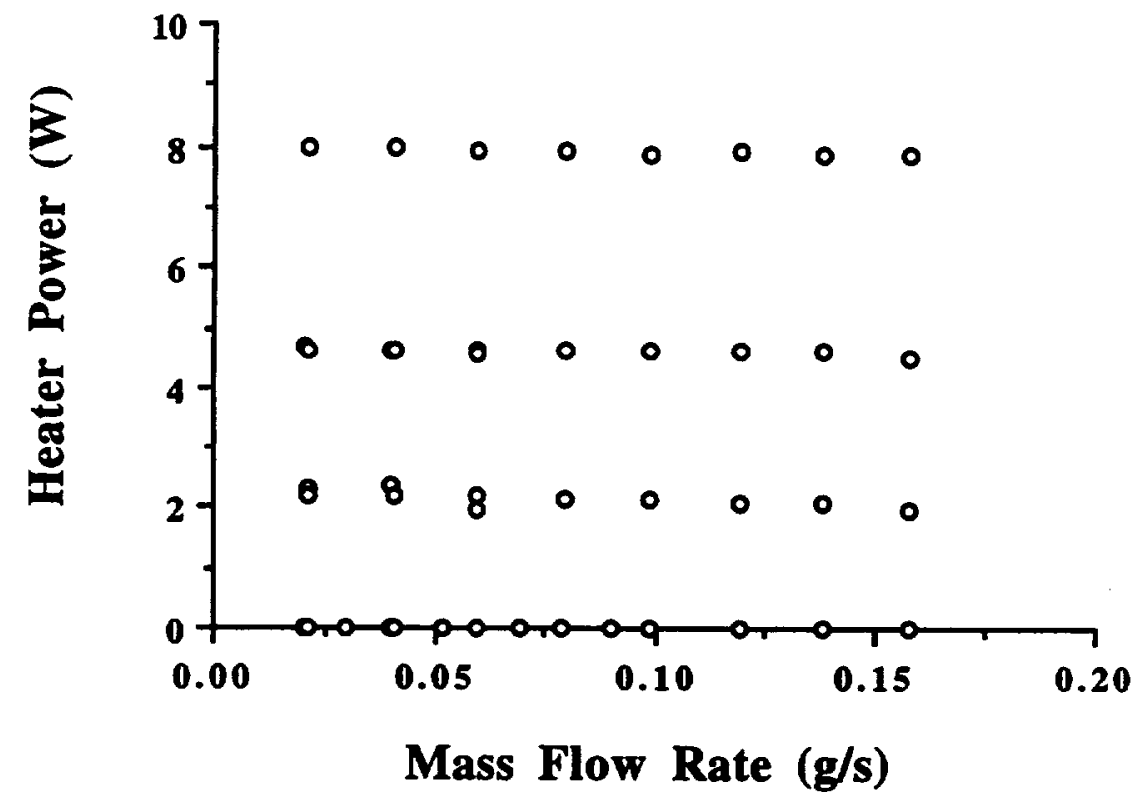

Figure 4 - Test Matrix for K10K Operating on N2

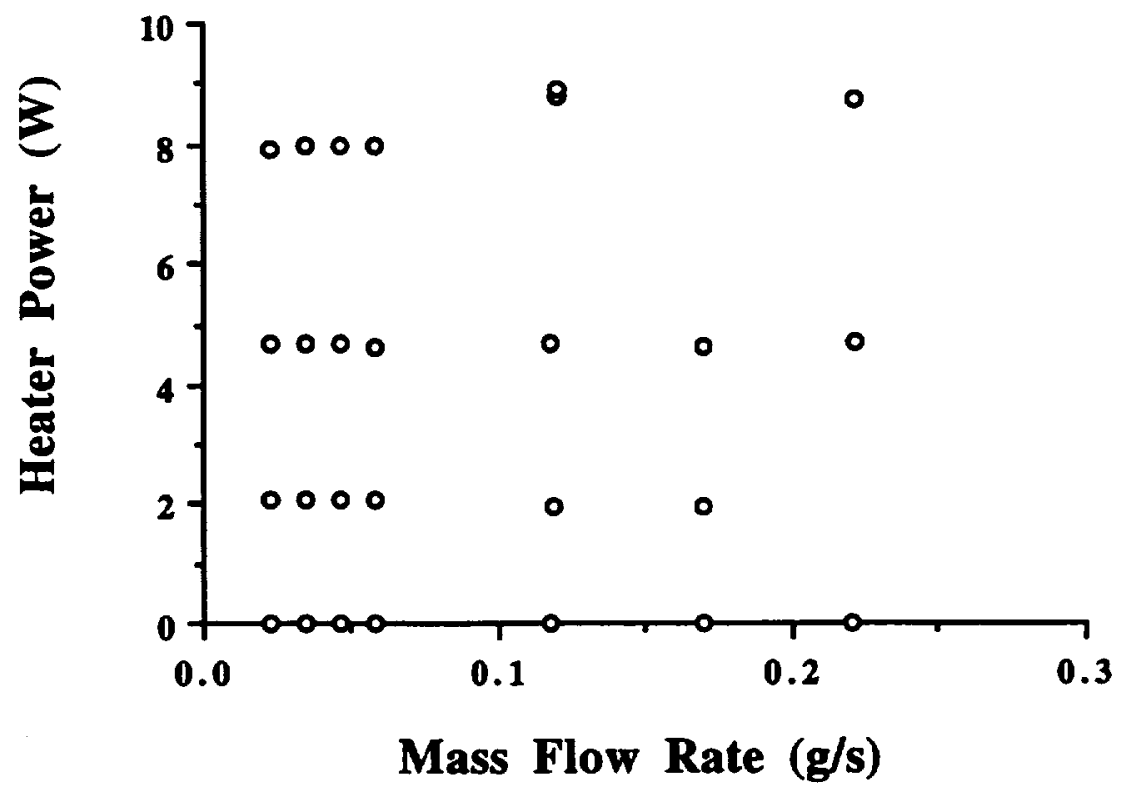

Figure 5 - Test Matrix for K10K Operating on Xe 


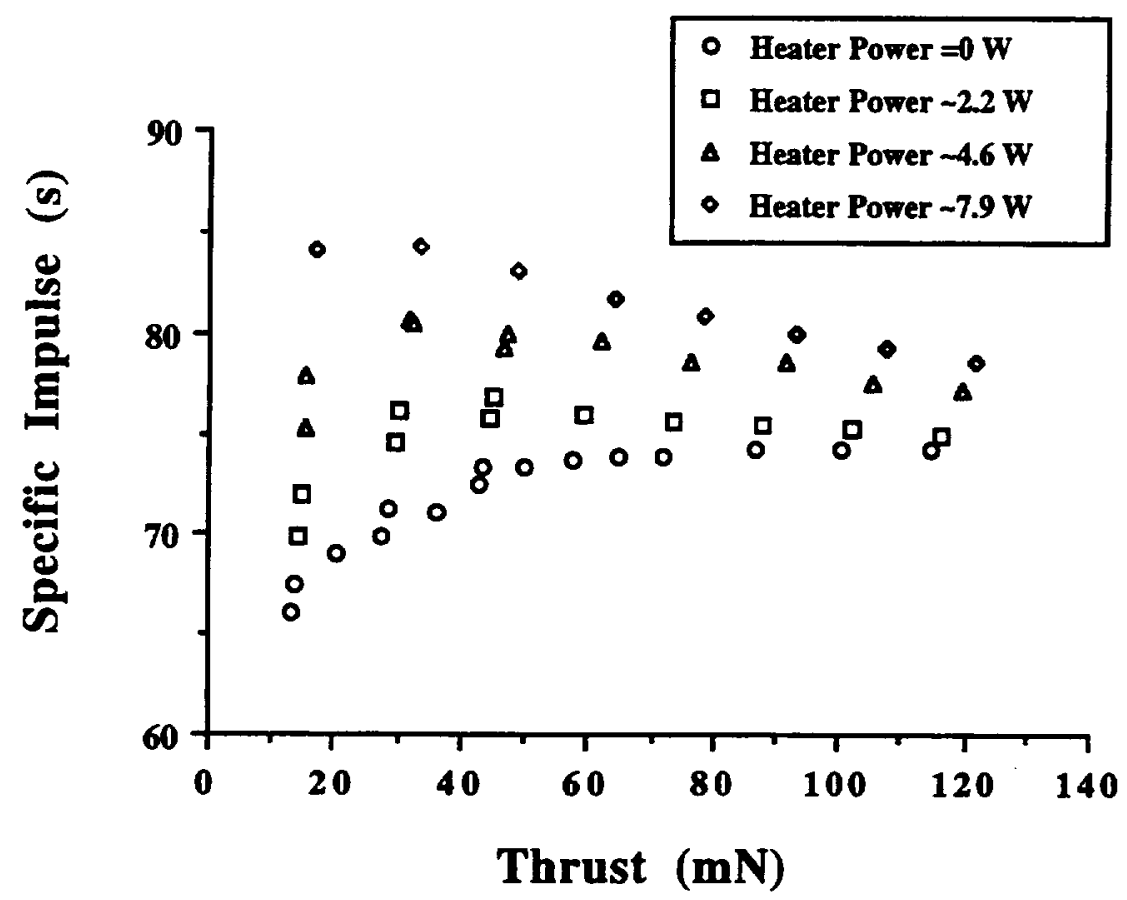

Figure 6 - Specific Impulse Versus Thrust for K10K Operating on N2 at Various Power Levels

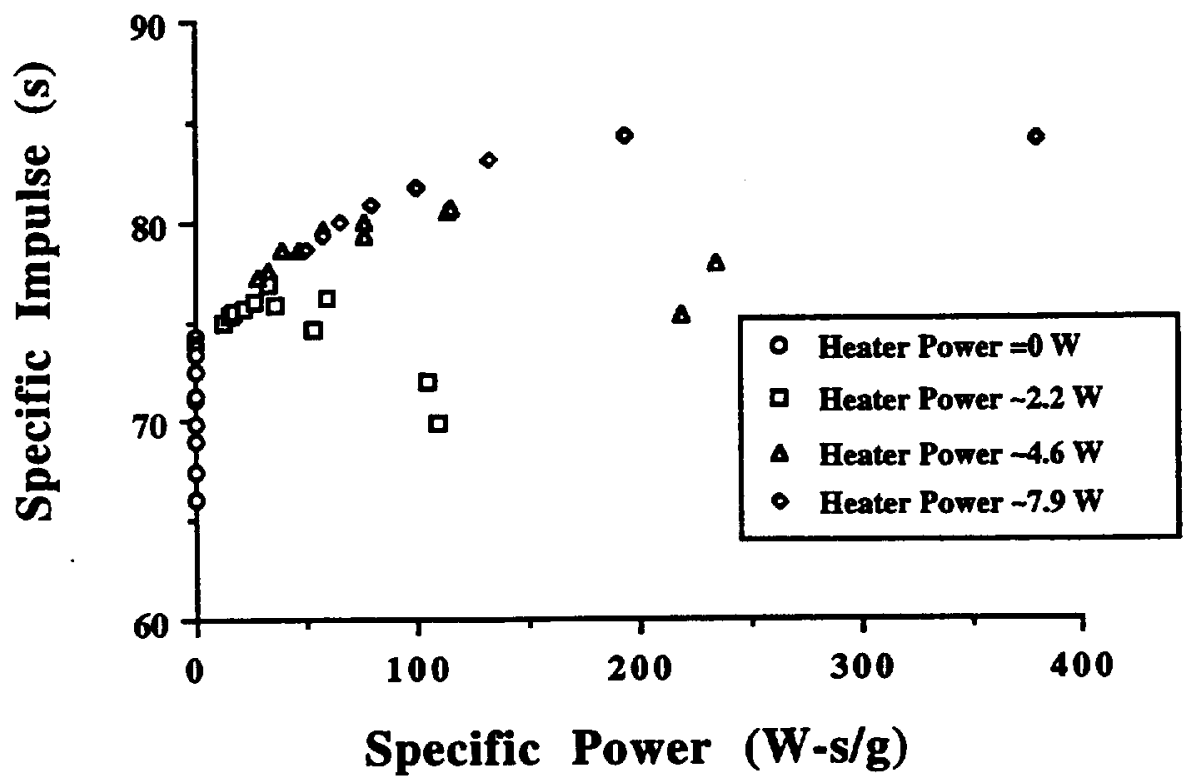

Figure 7 - Specific Impulse Versus Specific Power for K10K Operating on N2 at Various Power Levels 


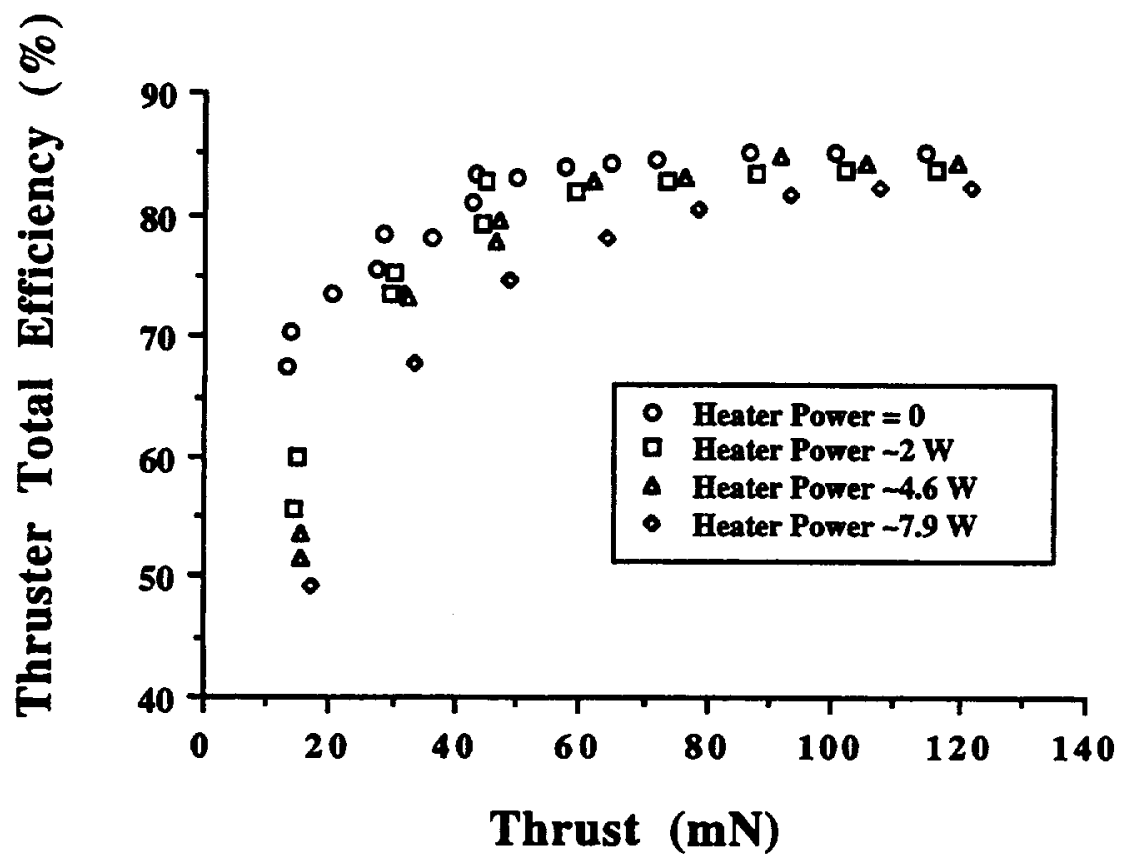

Figure 8 - Thruster Efficiency Versus Thrust for K10K Operating on N2 at Various Power Levels

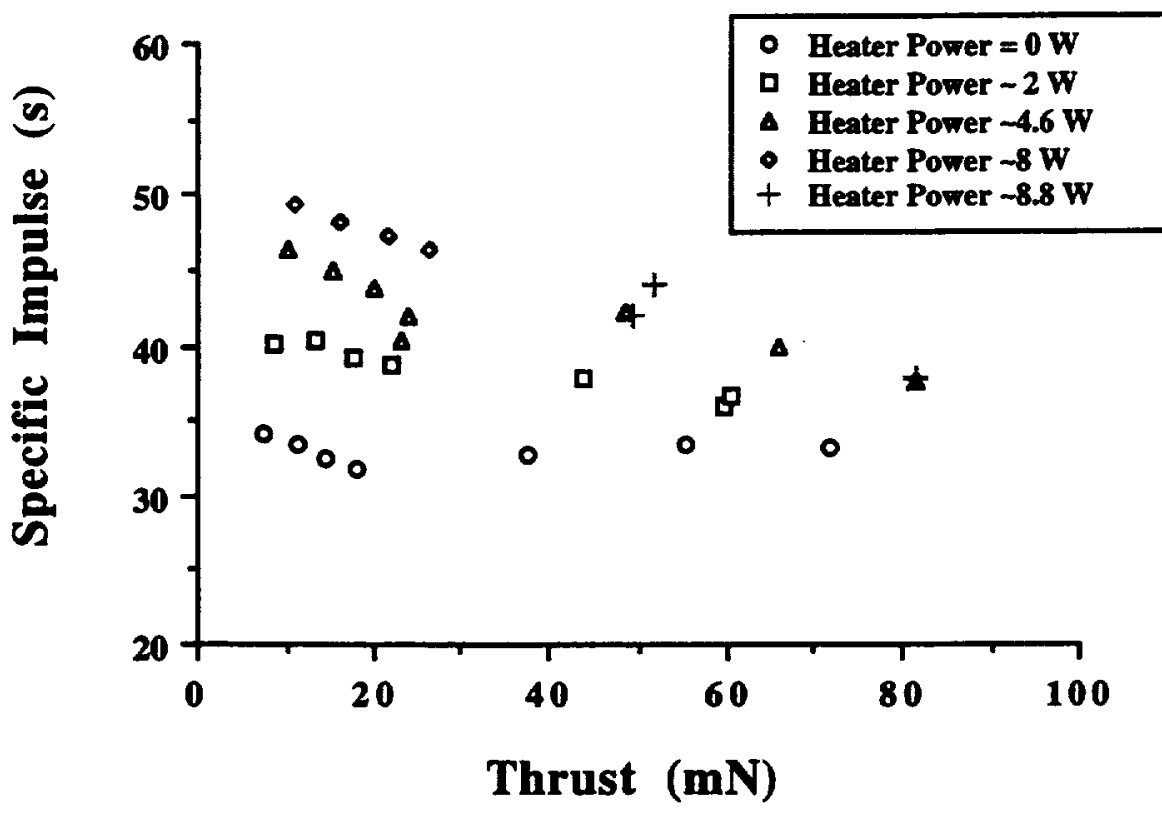

Figure 9 - Specific Impulse Versus Thrust for K10K Operating on Xe at Various Power Levels 


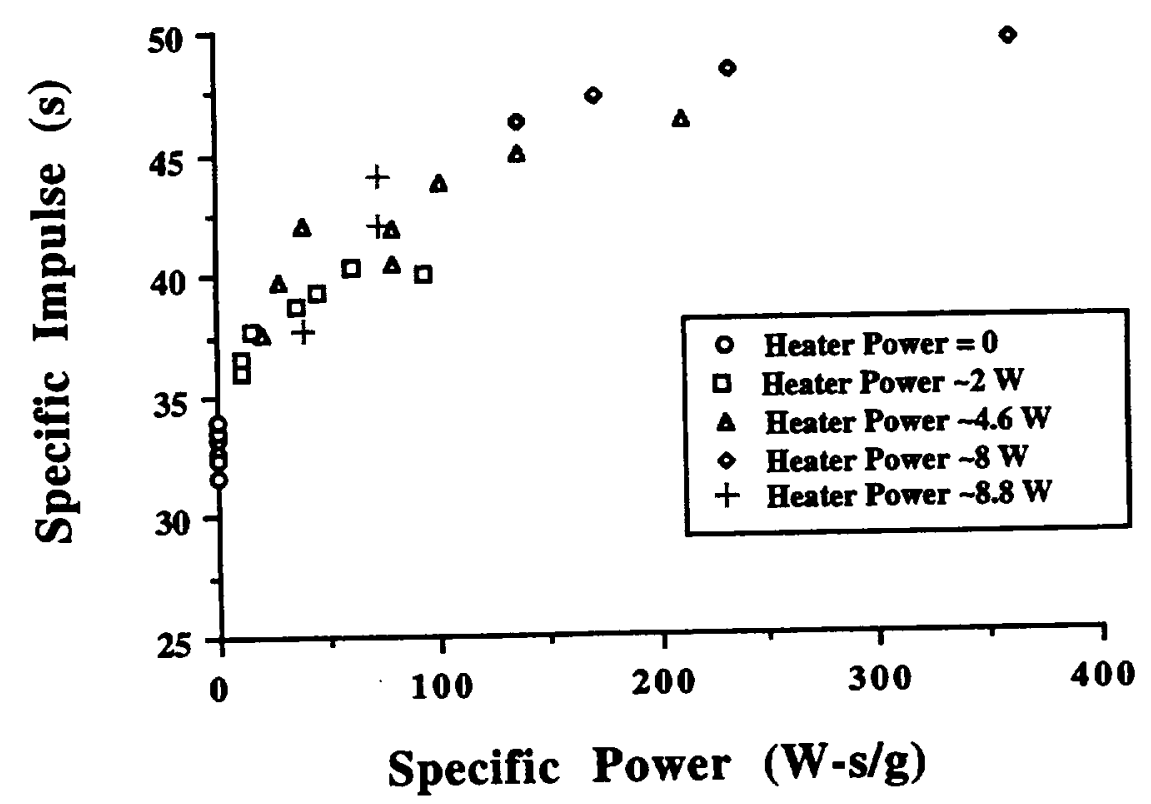

Figure 10 - Specific Impulse Versus Specific Power for K10K Operating on Xe at Various Power Levels

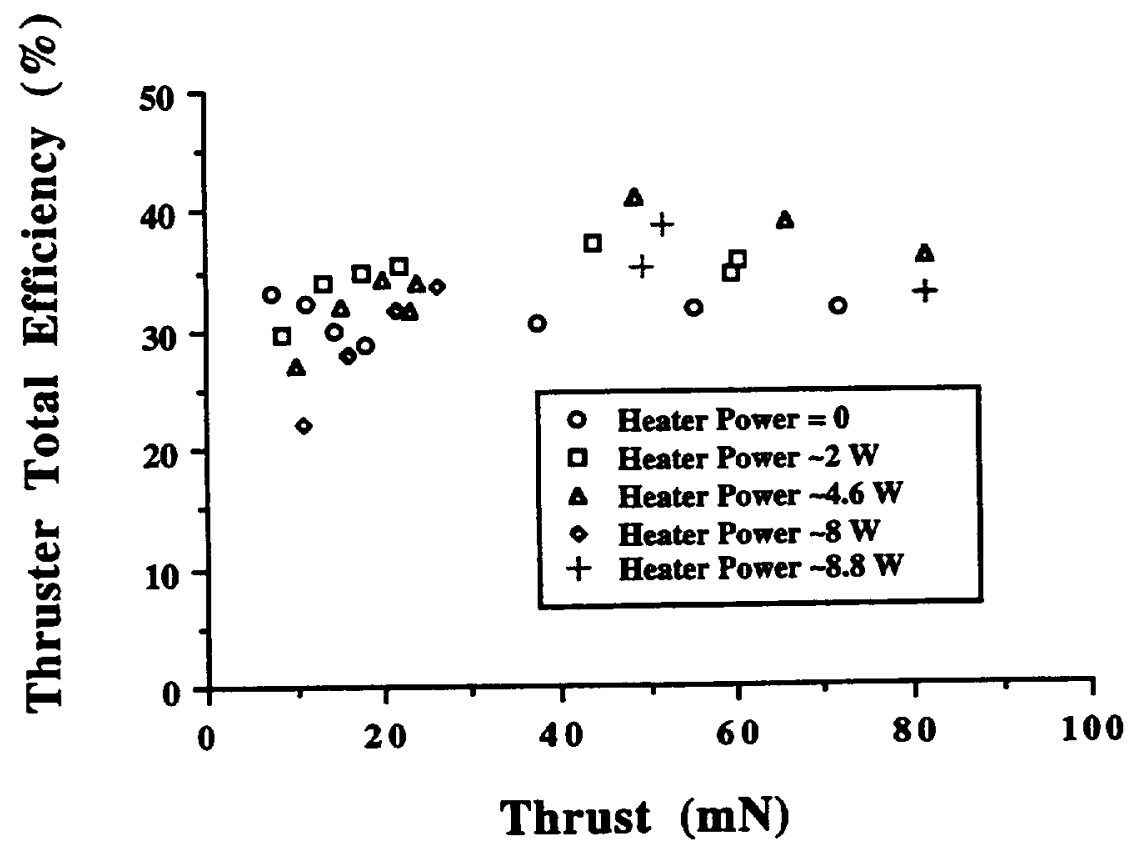

Figure 11 - Thruster Efficiency Versus Thrust for K10K Operating on Xe at Various Power Levels 
Public reporting burden for this collection of information is estimated to average 1 hour per response, including the time for reviewing instructions, searching exjsting deta sources, gathering and maintating the data needed, and completing and reviewing the collection of intormation. Send comments regarding this burden estimate or any other aspect of this collection of information, including suggestions for reducing this burden, to Washington Headquarters Services, Directorate lor Intormation Operations and Reports, 1215 Jetherson Davis Highway. Sulte 1204. Artington, VA 22202-4302, and to the Office of Management and Budget, Paperwork Reduction Project (0704-0188), Washington, DC 20503.

\begin{tabular}{|l|l|l}
\hline 1. AGENCY USE ONLY (Leave blank) & $\begin{array}{c}\text { 2. REPORT DATE } \\
\text { September } 1997\end{array}$ & $\begin{array}{r}\text { 3. REPOAT TYPE AND DATES COVERED } \\
\text { Technical Memorandum }\end{array}$
\end{tabular}

\section{TITLE AND SUBTITLE}

Performance of a FAKEL K10K Resistojet

\section{AUTHOR(S)}

Robert S. Jankovsky, John M. Sankovic, and Steven Oleson

\section{PERFORMING ORGANIZATION MAME(S) AND ADDRESS(ES)}

National Aeronautics and Space Administration

Lewis Research Center

Cleveland, Ohio 44135-3191

9. SPONSORING/MONITORING AGENCY NAME(S) AND ADDRESS(ES)

National Aeronautics and Space Administration

Washington, DC 20546-0001
5. FUNDING NUMBERS

WU-632-1B-1B-00
8. PERForming organization REPORT NUMBER

E-10897
10. SPONSORINGMONITORING AGENCY REPORT NUMBER

NASA TM-113127

\section{SUPPLEMENTARY NOTES}

Prepared for the 33rd Joint Propulsion Conference and Exhibit cosponsored by AIAA, ASME, SAE, and ASEE, Seattle, Washington, July 6-9, 1997. Robert S. Jankovsky, John M. Sankovic, NASA Lewis Research Center; Steven Oleson, NYMA, Inc., 2001 Aerospace Parkway, Brook Park, Ohio 44142 (work funded by NASA Contract NAS3-27186). Responsible person, Robert S. Jankovsky, organization code, 5430, (216) 433-7517.

12a. DISTRIBUTIONVAVAILABILITY STATEMENT 12b. DISTAIBUTION CODE

Unclassified - Unlimited

Subject Categories 13, 15, 16, and 20

This publication is available from the NASA Center for AeroSpace Information, (301) 621-0390.

13. ABSTRACT (Maximum 200 words)

A model K10K resistojet produced by FAKEL Enterprise was evauated at steady-state conditions with both nitrogen and xenon propellants. Performance and operational characteristics were documented for cold gas and heater power levels up to $8 \mathrm{~W}$ at mass flow rates from 0.02 to $0.2 \mathrm{~g} / \mathrm{s}$. Maximum specific impulses of $84 \mathrm{~s}$ on nitrogen and $49 \mathrm{~s}$ on xenon were achieved at the highest specific power levels tested.

\begin{tabular}{|c|c|}
\hline Resistojet; Thruster; Zen & \\
\hline $\begin{array}{l}\text { 17. SECURITY CLASSIFICATION } \\
\text { OF REPORT } \\
\text { Unclassified }\end{array}$ & $\begin{array}{l}\text { 18. SECURITY CLASSIFICATION } \\
\text { OF THIS PAGE } \\
\text { Unclassified }\end{array}$ \\
\hline
\end{tabular}

\begin{tabular}{|c|c|}
\hline & $\begin{array}{c}\text { 15. NUMBER OF PAGES } \\
13\end{array}$ \\
\hline & $\begin{array}{r}\text { 16. PRICE CODE } \\
\text { A03 }\end{array}$ \\
\hline $\begin{array}{l}\text { 19. SECUAITY CLASSIFICATION } \\
\text { OF ABSTRACT } \\
\text { Unclassified }\end{array}$ & 20. LMITATION OF ABSTRACT \\
\hline
\end{tabular}

